\title{
THE EXPERIMENTAL STUDY OF THE PATHOGENIC ROLE OF NADPH-OXIDASE IN THE THYROID GLAND TISSUES
}

\author{
Irina BAGMUT' ${ }^{1}$, Oleksii HALMIZ ${ }^{1}$, Svetlana GRAMATIUK ${ }^{1}$, Anna TITKOVA $^{1 凶}$, \\ Svetlana KRYZHNA ${ }^{1}$
}

${ }^{1}$ Department of Clinical Pathophysiology, Topographic Anatomy and Operative Surgery, Kharkiv Medical Academy of Postgraduate Education, Kharkiv, Ukraine

Received 11 Jan 2019, Accepted 25 Febr 2019

hitps://doi.org/10.31688/ABMU.2019.54.1.04

\section{Abstract}

The objective of the study was to compare the $\mathrm{NADPH} / \mathrm{H}_{2} \mathrm{O}_{2}$ system and the expression of enzymes in the culture of thyroid gland cells, depending on the sex.

Material and methods. The thyroid gland was collected from adult female donors $(n=20)$ and men $(n=15)$. The cells were washed twice with HBSS and centrifuged at $1000 \times \mathrm{g}$ for 5 minutes, and then cultured to 106 cells in $0.5 \mathrm{ml}$ culture medium per well in 24-well plates (Thermo Fisher Scientific, USA). $\mathrm{H}_{2} \mathrm{O}_{2}$ levels in the cells were determined quantitatively using a hydrogen peroxide sensor Premo ${ }^{\mathrm{TM}}$ Orp1-roGFP (Life Technologies, USA) according to manufacturer's instructions. Statistical analysis of the results was carried out using Statistica 6.1 (StatSoft, Inc., USA).

Results. We found that the expression of DUOX1 and NOX4 in the thyroid gland was significantly higher in women than in men (1.5 times, $\mathrm{p}<0.05)$. Expression of DUOX2 in female cells was 1.5 times higher than in men, but statistically significant $(p=0.06)$. We have found that the thyroid gland of women produces a significantly higher $\mathrm{H}_{2} \mathrm{O}_{2}$ content than the male gland cells $(p<0.05)$. The expression of DUOX1 and NOX4 is significantly higher in cells derived from the female thyroid gland than in cells derived from males. $\mathrm{H}_{2} \mathrm{O}_{2}$

\section{Résumé}

Étude expérimentale du rôle pathogénique de la NADPH-oxydase dans les tissus de la glande thyroïde

L'objectif de l'étude était de comparer le système $\mathrm{NADPH} / \mathrm{H} 2 \mathrm{O} 2$ et l'expression des enzymes, dans la culture de cellules de la glande thyroïde, en fonction du sexe.

Méthodes. La glande thyroïde a été prélevée chez des donneuses adultes $(n=20)$ et des hommes $(n=15)$. Les cellules ont été lavées deux fois avec du HBSS et centrifugées à 1000 xg pendant 5 minutes, puis cultivées à 106 cellules dans $0,5 \mathrm{ml}$ de milieu de culture par puits dans des plaques à 24 puits (Thermo Fisher Scientific, USA). Les niveaux de $\mathrm{H} 2 \mathrm{O} 2$ dans les cellules ont été déterminés de manière quantitative à l'aide d'un capteur de peroxyde d'hydrogène Premo TM Orp1-roGFP (Life Technologies, USA) conformément aux instructions du fabricant. L'analyse statistique des résultats a été réalisée avec Statistica 6.1 (StatSoft, Inc., USA).

Résultats. Nous avons constaté que l'expression de DUOX1 et de NOX4 était significativement plus élevée chez les femmes par rapport aux hommes (1,5 fois, $\mathrm{p}<0,05)$. L'expression de DUOX2 dans les cellules femelles était 1,5 fois plus élevée que celle des hommes mais statistiquement significative $(\mathrm{p}=0,06)$. Nous 
levels were also higher in cells derived from female thyroid gland than in male cells.

Conclusion. As a result of our experiment, the expression of DUOX1 and NOX4 is significantly higher in cells derived from the female thyroid gland than in cells derived from males. We have shown during the experiment that NOX4 is regulated both at the transcription level and at the level after transcription, and the level of sustained-release NOX4 mRNA does not accurately reflect the content and function of the NOX4 protein. Chronic effects on the female thyroid gland at higher concentrations of $\mathrm{H}_{2} \mathrm{O}_{2}$ can potentially cause many adverse effects.

Keywords: thyroid gland, NADPH oxidase, DUOX, hydrogen peroxide, oxidative stress.

\section{Abbreviations:}

ROS $=$ reactive oxygen species

$\mathrm{FAD}=$ flavin-adenin dinucleotide

$\mathrm{H}_{2} \mathrm{O}_{2}=$ hydrogen peroxide

DUOX1 = double oxidase 1

DUOX2 = double oxidase 2

NOX4 = NADPH oxidase 4

\section{INTRODUCTION}

Women are more susceptible to thyroid gland diseases than men. Both benign and malignant thyroid tumors are 3-4 times more likely to develop in women than in $\operatorname{men}^{1,2}$. The autoimmune diseases of the thyroid gland have also a higher prevalence in women than in men ${ }^{3,4}$. The exact cause and pathophysiological mechanisms of these different incidence and prevalence are still unknown. However, in recent years, many researchers have indicated that factors such as environmental, dietary or genetic factors are not responsible for this phenomenon ${ }^{5-8}$. On the other hand, data from an increasing number of studies show the influence of sex hormones - mainly estrogen - on the pathogenesis of proliferative and autoimmune diseases of the thyroid gland.

Experimental data indicate that estrogens are carcinogens and play an important role in the development of thyroid cancer. There are several mechanisms that are potentially responsible for this phenomenon. The metabolism of estrogens with cytochrome P450s leads to the formation of catechols, which, in turn, can be oxidized to intermediate compounds of chinones and semichinones that react with purine bases of DNA, which leads to depurinating adducts that generate highly mutagenic apuric sites ${ }^{7,9-11}$. Estrogen can also stimulate proliferation of thyroid avons constaté que la glande thyroïde des femmes produit une teneur en $\mathrm{H} 2 \mathrm{O} 2$ significativement plus élevée que les cellules de la glande masculine $(\mathrm{p}<0,05)$. Nous avons en fait montré que l'expression de DUOX1 et de NOX4 est significativement plus élevée dans les cellules dérivées de la glande thyroïde des femmes que dans celles dérivées des hommes. Les niveaux de $\mathrm{H} 2 \mathrm{O} 2$ étaient également plus élevés dans les cellules dérivées de la glande thyroïde féminine que dans les cellules masculines.

Conclusions. À la suite de notre expérience, l'expression de DUOX1 et de NOX4 est significativement plus élevée dans les cellules dérivées de la glande thyroïde des femmes que dans les cellules dérivées des hommes. Au cours de l'expérience, nous avons montré que NOX4 est régulé à la fois au niveau de la transcription et après, et que le niveau d'ARNm de NOX4 à libération prolongée ne reflète pas avec précision le contenu et la fonction de la protéine NOX4. Des effets chroniques sur la glande thyroïde femelle à des concentrations plus élevées en $\mathrm{H} 2 \mathrm{O} 2$ peuvent potentiellement causer de nombreux effets indésirables.

Mots-clés: glande thyroïde, NADPH oxydase, DUOX, peroxyde d'hydrogène, stress oxydatif.

cells, or, more likely, stem cells of the thyroid gland via the receptor-mediated pathway, or by enhancing the stimulation of thyroid gland NADPH oxidase $e^{12-15}$. This latter phenomenon is of particular importance, since it can explain not only the oncogenic ability of estrogen, but also the cause of the higher frequency of autoimmune diseases of the thyroid gland in women ${ }^{16-18}$. In addition, estrogens are involved in the regulation of angiogenesis and metastasis, which are crucial for the outcome of thyroid cancer ${ }^{19-20}$.

Somatic mutations are present at high levels in the rat thyroid gland, indicating that the thyrocyte is under oxidative stress, a state in which cellular oxidant levels are high. The most important class of free radicals, or reactive metabolites, is reactive oxygen species (ROS), such as superoxide anion, hydroxyl radical and hydrogen peroxide $\left(\mathrm{H}_{2} \mathrm{O}_{2}\right)^{21}$. The main source of ROS in every cell type seems to be mitochondrial respiration; however, recent data support the idea that NADPH: $\mathrm{O}_{2}$ ) oxidoreductase flavoproteins or simply NADPH oxidases (NOX) are enzymes specialized in controlled ROS generation at the subcellular level. Several decades ago, high concentrations of $\mathrm{H}_{2} \mathrm{O}_{2}$ were detected at the apical surface of thyrocytes, where thyroid hormone biosynthesis takes place.

Only in the last decade the enzymatic source of $\mathrm{H}_{2} \mathrm{O}_{2}$ involved in thyroid hormone biosynthesis has been well characterized. The cloning of two thyroid 
genes encoding NADPH oxidases dual oxidases 1 and 2 (DUOX1 and DUOX2) revealed that DUOX2 mutations lead to hereditary hypothyroidism in humans. Recent reports have also described the presence of NOX4 in the thyroid gland and have suggested a pathophysiological role of this member of the NOX family. In the present review, we describe the participation of NADPH oxidases not only in thyroid physiology but also in gland pathophysiology, particularly the involvement of these enzymes in the regulation of thyroid oxidative stress ${ }^{22-24}$.

The NADPH oxidase / dual oxidase family (NOX/DUOX) is a transmembrane protein that generates ROS as its major enzyme products. These are the flavoproteins that contain two gem-binding histidine and one NADPH binding site followed by a single flavin-adenine dinucleotide binding site $(\mathrm{FAD})^{25}$. Removal and transfer of the electron from the substrate NADPH to FAD, then gem and, finally, the molecular oxygen to form superoxide, which quickly turns into hydrogen peroxide $\left(\mathrm{H}_{2} \mathrm{O}_{2}\right)^{2}$. NADPH oxidase is a major non-mitochondrial AFC source in the cells. To date, three enzymes belonging to this group have been identified in the thyroid gland, namely, dual oxidase 1 (DUOX1), dual oxidase 2 (DUOX2) and NADPH oxidase 4 (NOX4). Both DUOX1 and DUOX2 are localized on thyrocytes, and their activation depends on an increase in the level of intracellular calcium.

The enzyme DUOX2 generates $\mathrm{H}_{2} \mathrm{O}_{2}$, which acts as an electron acceptor for biosynthesis of thyroid hormones. It is a dominant isoenzyme with a level of expression that is five times higher than that of DUOX1 ${ }^{26-28}$. The role of DUOX1 in the thyroid gland is still unknown. However, it is believed that it can function to overcome the lack of DUOX2 activity, at least under some uncertain circumstances.

From this perspective, there is a need for experimental studies on gender specific oxidative stress in order to find out the pathophysiological peculiarities that molecular mechanisms play in the gender disparity of thyroid gland diseases ${ }^{29}$.

THE AIM OF THIS STUDY was to compare the NADPH $/ \mathrm{H}_{2} \mathrm{O}_{2}$ system and the expression of enzymes, in the culture of thyroid gland cells, depending on sex.

\section{Materials AND Methods}

Cells culture. The thyroid gland was collected from adult female donors $(n=20)$ and men $(n=15)$. The glands were released from the connective tissue and crushed into small fragments using an electric homogenizer. After washing in Hanks's solution (HBSS) tissue fragments were incubated in $1 \mathrm{mg} / \mathrm{ml}$ collagenase
IV and $2.5 \mathrm{mg} / \mathrm{ml}$ trypsin in HBSS for 40 minutes at $37^{\circ} \mathrm{C}$, followed by filtration through a nylon mesh (100 $\mu \mathrm{m}$, Sigma-Aldrich, USA) to remove large fragments of tissue. The cells were washed twice with HBSS and centrifuged at $1000 \times \mathrm{g}$ for 5 minutes, and then cultured to 106 cells in $0.5 \mathrm{ml}$ culture medium per well in 24-well plates (Thermo Fisher Scientific, USA). The culture medium consisted of a modified Koon medium (Biochrom, Berlin, Germany) with $10 \%$ calf serum, $2 \mathrm{mM}$ glutamine, a mixture of five hormones $(1 \mathrm{mMU} / \mathrm{ml}$ thyrotropic hormone, $10 \mathrm{ng} /$ $\mathrm{ml}$ somatostatin, $10 \mu \mathrm{g} / \mathrm{ml}$ insulin, $1 \mathrm{nM}$ hydrocortisone and $5 \mu \mathrm{g} / \mathrm{ml}$ transferrin), $100 \mathrm{IU} / \mathrm{ml}$ penicillin-streptomycin and $2.5 \mu \mathrm{g} / \mathrm{ml}$ amphotericin B. Cells were maintained in a $\mathrm{CO}_{2}$ incubator at $37^{\circ} \mathrm{C}(95: 5 \%)$.

Assessment of $\mathrm{H}_{2} \mathrm{O}_{2}$ level. $\mathrm{H}_{2} \mathrm{O}_{2}$ levels in the cells were determined quantitatively using a hydrogen peroxide sensor Premo ${ }^{\mathrm{TM}}$ Orp1-roGFP (Life Technologies, USA) according to manufacturer's instructions. The plasmid DNA encoding Orp1-roGFP was delivered to the cell by transduction. The cells were transduced with the Orp1-roGFP oxidation-reducing probe immediately after sowing, fluorescence was measured in a micro printer reading machine Synergy H1 (BioTek, USA) using excitation at $400 \mathrm{~nm}$ and $488 \mathrm{~nm}$ and emission at $515 \mathrm{~nm}$. The values of the fluorescence intensity were used to calculate the $400 / 488 \mathrm{~nm}$ excitation ratios. The results are expressed in terms of the excitement ratio in untreated cells.

Statistical analysis of the results was carried out using the computer software package for statistical information processing Statistica 6.1 (StatSoft, Inc., USA).

\section{Results}

In the first phase of the experimental study, we analyzed the expression of NOX/DUOX and the level of $\mathrm{H}_{2} \mathrm{O}_{2}$ in the primary cells derived from the thyroid gland of men and women. A total RNA from primary thyroid gland of males and females was isolated and a polymerase chain reaction was performed to determine DUOX1, DUOX2 and NOX4 (Figure 1).

We found that the expression of DUOX1 and NOX4 was significantly higher in women in thyroid gland than in men (1.5 times, $p<0.05)$. Expression of DUOX2 in female cells was 1.5 times higher than that of men, but statistically significant $(\mathrm{p}=0.06)$.

We examined the intracellular level of this molecule to check whether these genes are elevated in women to increase $\mathrm{H}_{2} \mathrm{O}_{2}$ production. Since chemical probes commonly used to detect intracellular AFKs do not have the specificity of the type of AFK produced, we used the recently developed Orp1-roGFP sensor to measure $\mathrm{H}_{2} \mathrm{O}_{2}$ levels in cells. We have found that 


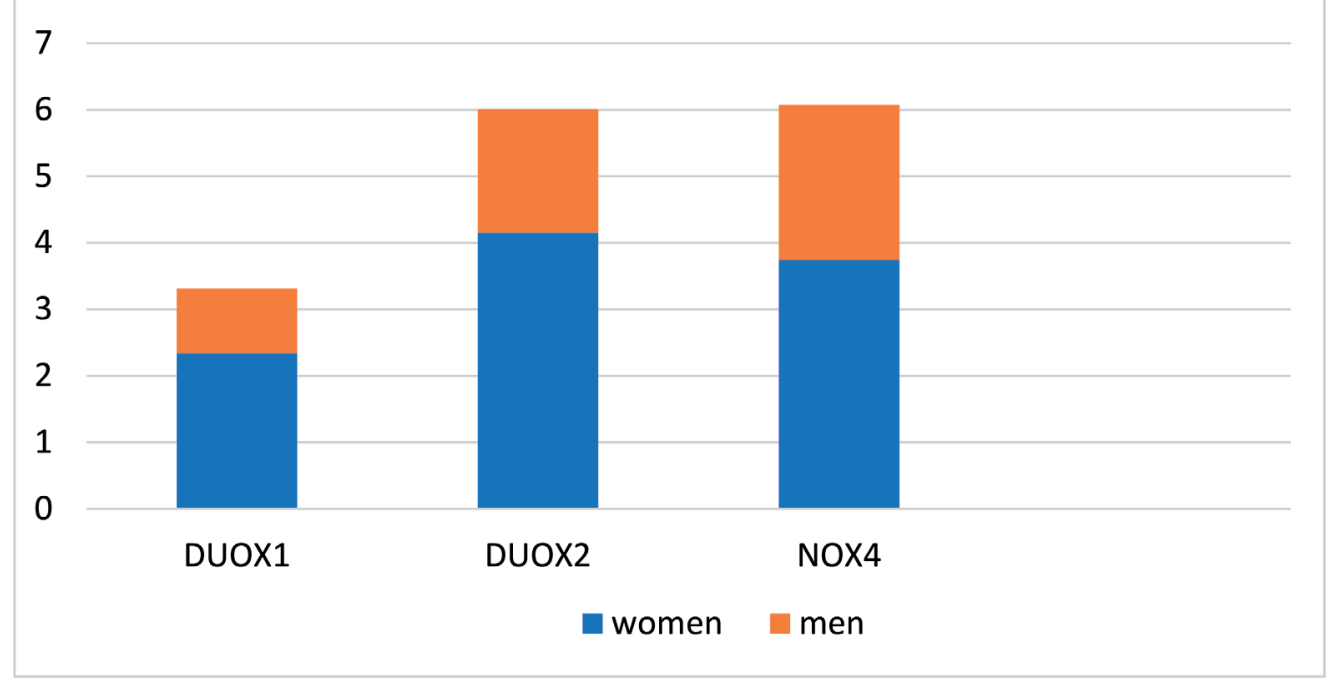

Figure 1. Expression of DUOX1, DUOX2 and NOX4 in thyroid gland cells in $\log 2$. Expression of mRNA was determined using real time PCR. $* \mathrm{p}<0.05$

in women the thyroid gland produces a significantly higher $\mathrm{H}_{2} \mathrm{O}_{2}$ content than male gland cells $(\mathrm{p}<0.05)$.

We have actually shown that the expression of DUOX1 and NOX4, the main non-mitochondrial sources AFK, is significantly higher in cells derived from the thyroid gland of women than in cells derived from males.

We also measured the cellular level of $\mathrm{H}_{2} \mathrm{O}_{2}$, the major enzymatic product of NOX / DUOX enzymes. It was found that $\mathrm{H}_{2} \mathrm{O}_{2}$ levels were also higher in cells derived from female thyroid gland than in male cells.

\section{Discussion}

On the apical membrane of thyrocytes, $\mathrm{H}_{2} \mathrm{O}_{2}$ acts as a TPO co-substrate in thyroid hormone biosynthesis. The sources of thyrocyte $\mathrm{H}_{2} \mathrm{O}_{2}$ related to hormone genesis are the DUOX enzymes, DUOX1 and DUOX2, which have two calcium-binding sites that are indispensable for their activities. Another NOX family member, NOX4, has recently been described in thyrocytes and, in contrast with DUOX, it seems to mainly generate ROS in the intracellular compartment and is constitutively active ${ }^{30}$.

Apart from its role in thyroid hormonogenesis, $\mathrm{H}_{2} \mathrm{O}_{2}$ is normally produced by all cells of living organisms, and it is able to act in the redox-dependent regulation of different cellular functions, including response to stressors, angiogenesis, and cell proliferation, among others. Conceptually, an imbalance between pro-oxidant compounds and antioxidant defences leads to the disruption of redox signaling and control ${ }^{31}$.

Thus, $\mathrm{H}_{2} \mathrm{O}_{2}$ has been linked to various processes related to the development of thyroid nodules and cancer, such as cellular proliferation, DNA damage and apoptosis inhibition. As a result, the enzymes involved in thyroid ROS generation might be implicated not only in thyroid physiology but also in gland pathophysiology in a gender-specific manner. Thus, the mechanisms underlying the regulation of thyroid ROS generation and detoxification need to be further clarified $^{32} 34$.

Excessive production of microparticles induced by constant cell activation may contribute to the development of chronic inflammatory processes and propensity to autoimmune diseases ${ }^{35}$.

Experimental data show that the effect of hormonal factors, especially estrogen, may explain the damage by autoimmune thyroid diseases in women. Liu et $\mathrm{al}^{16}$ demonstrated higher serum levels of estrogen, follicle stimulating hormone and luteinizing hormone (and their receptors) in thyroid tissue in patients with different types of tumors, which suggests that thyroid gland tumors may depend on sex hormones.

It is believed that oxidative stress can be at the heart of pathogenic mechanisms, both proliferative and autoimmune diseases of the thyroid gland ${ }^{35}$. As a result of our experiment, the expression of DUOX1 and NOX4 is significantly higher in cells derived from the thyroid gland of women than in cells derived from males. This is consistent with the results of previous experimental animal studies in which sexual malformation was detected in the expression of NOX4 and DUOX1 16-17,19-20.

Moreover, it has been demonstrated that increased regulation of expression of DUOX1 may also be at the basis or contributing to autoimmune thyroid gland diseases. It should be emphasized that the levels of mRNA do not necessarily reflect the protein levels 
and the amount of AFC formation ${ }^{36}$. We have shown during the experiment that NOX4 is regulated both at the transcription level and at the level after transcription, and the level of sustained-release NOX4 mRNA does not accurately reflect the content and function of the NOX4 protein. For these reasons, we also measured the cellular level of $\mathrm{H}_{2} \mathrm{O}_{2}$, the major enzymatic product of NOX / DUOX enzymes. It was found that $\mathrm{H}_{2} \mathrm{O}_{2}$ levels were also higher in cells derived from female thyroid gland than in male cells. Chronic effects of higher concentrations of $\mathrm{H}_{2} \mathrm{O}_{2}$ on the female thyroid gland can potentially cause many adverse effects.

\section{Conclusions}

Higher concentrations of $\mathrm{H}_{2} \mathrm{O}_{2}$ can be a pathophysiological link in the role of an oxidant, and damage macromolecules such as proteins, lipids and nucleic acids. In addition, $\mathrm{H}_{2} \mathrm{O}_{2}$, acting as a signaling molecule, can cause a higher rate of cell proliferation and suppression of apoptosis. All these may be due to an increased risk of thyroid gland diseases. Oxidative stress itself can be at the heart of pathogenic mechanisms of proliferative and autoimmune diseases of the thyroid gland.

In our opinion, the future treatment of autoimmune dysfunction of the thyroid gland should be aimed at restoring immune tolerance. We plan to carry out some experiments that could allow better understanding of pathogenesis of autoimmune thyroid lesions of the thyroid gland in its surgical pathology, including the measurement of the functionality of IL-10 produced by Breg cells, or the characterization of the phenotype of these cells in the thyroid tissue. Clarifying more detailed information on the regulation of immune responses by Breg cells can provide the basis for the development of new B-cell therapeutic strategies in these patients.

\section{Acknowledgements}

We thank all the members of the research team.

\section{Compliance with Ethics Requirements:}

"The authors declare no conflict of interest regarding this article"

„The authors declare that all the procedures and experiments of this study respect the ethical standards in the Helsinki Declaration of 1975, as revised in 2008(5), as well as the national law. Informed consent was obtained from all the patients included in the study"

$$
\text { „No funding for this study" }
$$

\section{References}

1. James BC, Mitchell JM, Jeon HD, Vasilottos N, Grogan RH. An update in international trends in incidence rates of thyroid cancer, 1973-2007. J Cancer Causes Control. 2018;29:465-473.

2. Spencer WA, Vadhanam MV, Jeyabalan J, Gupta RC. Oxidative DNA damage following microsome/ $\mathrm{Cu}(\mathrm{II})$-mediated activation of the estrogens, $17 \beta$-estradiol, equilenin, and equilin: role of reactive oxygen species. $J$ Chem Res Toxicol. 2012;25:305-314. Hollowell JG. Serum TSH, T4, and thyroid antibodies in the United States population. National Health and Nutrition Examination Survey (NHANES III). J Clin Endocrinol Metab. 2002;87:489-499.

3. Kabat GC, Kim MY. Menstrual and reproductive factors, exogenous hormone use, and risk of thyroid carcinoma in postmenopausal women. J. Cancer Causes Control. 2012;23: 2031-2040.

4. Barker CE, Ali S, O’Boyle G, Kirby JA. Transplantation and inflammation: implications for the modification of chemokine function. J Immunology. 2014;143:138-145.

5. Rahbari R, Zhang L, Kebebew E. Thyroid cancer gender disparity. J Future Oncol. 2010;6:1771-1779.

6. Schonfeld SJ, Neta G, Sturgis EM, Pfeiffer RM, Hutchinson AA. Common genetic variants in sex hormone pathway genes and papillary thyroid cancer risk. J Thyroid. 2012;22: 151-156.

7. Cooke PS, Nanjappa MK, Ko C, Prins GS. Estrogens in male physiology. J Physiol Rev. 2017;97:995-1043.

8. Ng CS, Lau KK. Surgical trauma and immune functional changes following major lung resection. Indian J Surg. 2015;77:49-54. Barakat R, Oakley O. Extra-gonadal sites of estrogen biosynthesis and function. J BMB Rep. 2016;49:488-496.

9. Stanczyk FZ, Clarke NJ. Measurement of estradiol--challenges ahead. J Clin Endocrinol. Metab. 2014;99:56-58.

10. Hammes SR, Levin ER. Extranuclear steroid receptors: Nature and actions. J Endocr Rev. 2007;28:726-741.

11. Gala F, Piñeiro P, Reyes A. Postoperative pulmonary complications, pulmonary and systemic inflammatory responses after lung resection surgery with prolonged one-lung ventilation. Randomized controlled trial comparing intravenous and inhalational anaesthesia. Br J Anaesth. 2017;119:655663.

12. Levin ER. Plasma membrane estrogen receptors. J Trends Endocrinol Metab. 2009;20:477-482.

13. Maggiolini M, Picard D. The unfolding stories of GPR30, a new membrane-bound estrogen receptor. J Endocrinol. 2010;204:105-114.

14. Magri F, Capelli V, Gaiti M, Villani L. ER-alpha and ER-beta expression in differentiated thyroid cancer: Relation with tumor phenotype across the TNM staging and peri-tumor inflammation. J Endocrine. 2015;49:429-435.

15. Wang H, Hu B, Zou Y, Bo L. Dexmedetomidine premedication attenuates concanavalin A-induced hepatitis in mice. J. Toxicol Sci. 2014;39:755-764.

16. Liu J, Chen, G. Serum levels of sex hormones and expression of their receptors in thyroid tissue in female patients with various types of thyroid neoplasms. J Pathol Res Pract. 2014;210:830-835.

17. Cavalieri EL, Rogan EG, Zahid M. Critical depurinating DNA adducts: estrogen adducts in the etiology and prevention of cancer and dopamine adducts in the etiology and prevention of Parkinson's disease. Int J Cancer. 2017;141:1078-1090. 
18. Ueki M, Kawasaki T, Habe K, Hamada K. The effects of dexmedetomidine on inflammatory mediators after cardiopulmonary bypass. J Anesthesia. 2014; 69:693-700.

19. Kurosawa S, Kato M. Anesthetics, immune cells, and immune responses. J Anesth. 2008;22:263-277.

20. Cardinale F, Chinellato I, Caimmi S, Peroni DG. Perioperative period: immunological modifications. Int $J$ Immunopathol Pharmacol. 2017;24:S3:9-12.

21. Webster NR, Galley HF. Immunomodulation in the critically ill. Br J Anaesth. 2009;103:70-81.

22. Singh R, Aggarwal A, Misra R. Th1/Th17 cytokine profiles in patients with reactive arthritis/undifferentiated spondyloarthropathy. J Rheumatol. 2007;34:2285-2290.

23. Guo NH, Shi QZ. Expression of regulatory T cells and Th17 cells in idiopathic thrombocytopenic purpura and its significance. Br J Anaesth. 2018;102:610-612.

24. Ledue TB, Weiner DL, Sipe JD. Analytical evaluation of particle-enhanced immunonephelometric assays for C-reactive protein, serum amyloid $\mathrm{A}$, and mannose-binding protein in human serum. J Ann Clin Biochem. 1998;35:745-753.

25. Zhang Y, Ma D, Zhang Y, Tian Y, Wang X. The imbalance of Th17/Treg in patients with uterine cervical cancer. J Clin Chim Acta. 2016;412:894-900.

26. Elenkov IJ, Chrousos GP. Stress hormones, proinflammatory and anti-inflammatory cytokines, and autoimmunity. J Ann N Y Acad Sci. 2012;966:290-303.

27. Weatherby KE, Zwilling BS, Lafuse WP. Resistance of mac rophages to Mycobacterium avium is induced by alpha2-adr energic stimulation. J Infect Immun. 2003;71:22-29.

28. Sherman TS, Chambliss KL, Gibson LL, et al. Estrogen acutely activates prostacyclin synthesis in ovine fetal pulmonary artery endothelium. Am J Respir Cell Mol Biol. 2014;26:610-616.

29. Mori M, Tsukahara F, Yoshioka T, Irie K, Ohta H. Suppression by 17 betaestradiol of monocyte adhesion to vascular endothelial cells is mediated by estrogen receptors. Life Sci. 2014;75:599-609.

30. Muhn P, Fuhrmann U, Fritzemeier K, et al. Drospirenone: a novel progestogen with antimineralocorticoid and antiandrogenic activity. In Steroid receptors and antihormones. Ann NY Acad. Sci. 2015;761:311-331.

31. Araki N, Iida M, Amino N. Rapid Rapid bioassay for detection of thyroid-stimulating antibodies using cyclic adenosine monophosphate-gated calcium channel and aequorin. J Eur Thyroid. 2015;4:14-19.

32. Diana T, Krause J, Olivo PD, Konig J. Prevalence and clinical relevance of thyroid stimulating hormone receptor-blocking antibodies in autoimmune thyroid disease. Clin Exp Immunol. 2017;189:304-309.

33. Abeillon-du Payrat J, Chikh K, Bossard N, Bretones P. Predictive value of maternal second-generation thyroid-binding inhibitory immunoglobulin assay for neonatal autoimmune hyperthyroidism. Eur J Endocrinol. 2014;171:451-460.

34. Grasberger H, De Deken X, Mayo OB, et al. Mice deficient in dual oxidase maturation factors are severely hypothyroid. Mol Endocrinol. 2012;26:481-492.

35. Moisa C, Gaman MA, Diaconu C, Assani AD, Gaman AM. The evaluation of oxidative stress in patients wih essential thrombocythemia treated with risk-adapted therapy. Arch Balk Med Union 2018;53(4):529-534.

36. Yoshihara A, Hara T, Kawashima A, et al. Regulation of dual oxidase expression and $\mathrm{H} 2 \mathrm{O} 2$ production by thyroglobulin. Thyroid. 2012;22:1054-1062. 